\title{
Karyotype analysis of two oribatid mite species (Acari: Oribatida)
}

\author{
Nisa GÜMÜŞ1 (D), Halil Erhan EROĞLU² (D), Sedat PER ${ }^{3,4}$ (D) \\ ${ }^{1}$ Department of Biology, Institute of Natural and Applied Sciences, Yozgat Bozok University, Yozgat, Turkey \\ ${ }^{2}$ Department of Biology, Faculty of Sciences and Letters, Yozgat Bozok University, Yozgat, Turkey \\ ${ }^{3}$ Department of Chemistry and Chemical Processing Technology, Mustafa Çılkrıkçıoğlu Vocational School, Kayseri University, \\ Kayseri, Turkey \\ ${ }^{4}$ Corresponding author: sedatper@kayseri.edu.tr
}

Received: 18 January 2022

Accepted: 23 January 2022

Available online: 27 January 2022

\begin{abstract}
The chromosomal parameters and karyotypic relationships may provide very valuable information about speciation and karyotype evolution. In the order Oribatida, the chromosomal data are limited to a few reports. In the present study, the chromosomal data of two species are provided for the first time. The diploid chromosome numbers are $2 n=14$ in Oribotritia hermanni Grandjean, 1967 (Oribatida: Oribotritiidae) and $2 n=22$ in Hermanniella gibber Kulijev, 1979 (Oribatida: Hermanniellidae) and chromosomes are small holocentric chromosomes. The smallest and largest chromosome sizes are $0.38 \mu \mathrm{m}$ and $1.08 \mu \mathrm{m}$ in 0 . hermanni, respectively. The total haploid chromosome length is 4.88 $\mu \mathrm{m}$, in 0 . hermanni, and a higher value of $6.98 \mu \mathrm{m}$ is recorded in $H$. gibber. The sex chromosomes could not be identified, because the oribatid mites show weak sexual dimorphism. In this respect, the results of the study provide important contributions to the cytotaxonomy of oribatid mites.
\end{abstract}

Keywords: Acari; Oribatida, karyotype, holocentric chromosome, Turkey.

Zoobank: http://zoobank.org/7F0A897D-E77E-4965-BFB9-4E6B4653EAD9

\section{INTRODUCTION}

Soil, which hosts more than a quarter of all living species in the world, is an extremely complex system. It also comprises a large variety of small invertebrates, such as nematodes, pauropods, pseudoscorpions, myriapods, springtails and mites, other invertebrates or microorganisms (Schuppenhaurer et al., 2019). Acari, commonly known as mites and ticks is a member of the class Arachnida and may be among the most species-rich groups of animals, after insects and possibly nematodes (Dabert, 2005). Oribatid mites form one of the most dominant arthropod groups of the soil fauna, particularly abundant and diverse in moist forest floors. They feed on decaying plant remains and fungi (Heethoff et al., 2007; Bezci and Baran, 2016; Norton and Franklin, 2018).

So far, there are approximately 11332 species of oribatid mites in 1306 genera belonging to 162 families identified (Subías, 2004). However, in a very small number of species, the chromosome number has been reported. In addition, oribatid mites are a valuable model for holocentric chromosomes in cytogenetic studies. Generally, the number of diploid chromosomes in oribatid mites is $2 n=18$, though some have $2 n=16$ and 30 (Oliver, 1977; Norton et al., 1993; Eroğlu and Per, 2016; Gümüş et al., 2018). Although there are numerous morphological and systematic studies on Hermanniella gibber Kulijev and Oribotritia hermanni Grandjean, there is no information about their karyotype and chromosome number. The present study aimed to investigate the chromosomal data and karyotype analyses of $H$. gibber and $O$. hermanni.

\section{MATERIALS AND METHODS}

Oribatid mites sampling and locations

Specimens of Hermanniella gibber and Oribotritia hermanni were collected from Turkey's Sakarya (Kılıçkaya Hill) and Çorum (Laçin district) provinces. The collecting data of $H$. gibber is: Çorum: Laçin, Laçin district, $40^{\circ} 46.278^{\prime} \mathrm{N}, 34^{\circ} 52.793^{\prime} \mathrm{E}, 779 \mathrm{~m}$, soil, 19 October 2014, 35 exs.; $40^{\circ} 46.215^{\prime} \mathrm{N}, 34^{\circ} 52.848^{\prime} \mathrm{E}, 830 \mathrm{~m}$, moss on rock, 19 October 2014, 1 ex.; $40^{\circ} 46.247^{\prime} \mathrm{N}, 34^{\circ} 52.868^{\prime} \mathrm{E}, 788 \mathrm{~m}$, soil, 19 October 2014, 13 exs.; $40^{\circ} 46.224^{\prime} \mathrm{N}, 34^{\circ} 53.009^{\prime} \mathrm{E}$, 813 m, moss on Pinus sp., 19 October 2014, 16 exs. (3 exs mounted on aluminum stubs and gold-coated for scanning electron microscopy); $40^{\circ} 46.284^{\prime} \mathrm{N}, 34^{\circ} 52.654^{\prime} \mathrm{E}$, $817 \mathrm{~m}$, soil, 30 October 2014, 4 exs.; $40^{\circ} 46.269^{\prime} \mathrm{N}$, $34^{\circ} 52.500^{\prime} \mathrm{E}, 834 \mathrm{~m}$, moss on Pinus sp., 30 October 2014,3 exs.; $40^{\circ} 46.283^{\prime} \mathrm{N}, 34^{\circ} 52.476^{\prime} \mathrm{E}, 813 \mathrm{~m}$, soil, 30 October 2014, 5 exs.; $40^{\circ} 46.293^{\prime} \mathrm{N}, 34^{\circ} 52.378^{\prime} \mathrm{E}, 800 \mathrm{~m}$, moss on Pinus sp., 30 October 2014, 9 exs.; $40^{\circ} 46.090^{\prime} \mathrm{N}$, $34^{\circ} 52.757^{\prime}$ E, $882 \mathrm{~m}$, soil, 29 October 2015, 1 ex.; $40^{\circ} 46.215^{\prime} \mathrm{N}, 34^{\circ} 53.170^{\prime} \mathrm{E}, 748 \mathrm{~m}$, lichen on rock, 07 November 2015, 3 exs.; $40^{\circ} 46.112^{\prime} \mathrm{N}, 34^{\circ} 53.225^{\prime} \mathrm{E}, 822 \mathrm{~m}$, soil, 07 November 2015, 2 exs.; $40^{\circ} 46.025^{\prime} \mathrm{N}, 34^{\circ} 53.241^{\prime}$ E, 882 m, moss, 07 November 2015, 2 exs.; 40 $45.698^{\prime} \mathrm{N}$, $34^{\circ} 52.182^{\prime} \mathrm{E}, 987 \mathrm{~m}$, soil, 17 April 2016, 6 exs.; $40^{\circ} 45.631^{\prime}$ $\mathrm{N}, 34^{\circ} 52.054^{\prime} \mathrm{E}, 960 \mathrm{~m}$, moss, 17 April 2016, 1 ex.; $40^{\circ} 45.862^{\prime} \mathrm{N}, 34^{\circ} 52.818^{\prime} \mathrm{E}, 995 \mathrm{~m}$, soil, 01 August 2016, 3 exs.; $40^{\circ} 45.929^{\prime} \mathrm{N}, 34^{\circ} 52.680^{\prime} \mathrm{E}, 995 \mathrm{~m}$, soil, 01 August 2016, 1 ex.; $40^{\circ} 45.903^{\prime} \mathrm{N}, 34^{\circ} 52.687^{\prime} \mathrm{E}, 1001 \mathrm{~m}$, soil, 01 August 2016, 3 exs.; $40^{\circ} 45.641^{\prime} \mathrm{N}, 34^{\circ} 52.848^{\prime} \mathrm{E}, 1070 \mathrm{~m}$, soil, 01 August 2016, 4 exs.; $40^{\circ} 45.612^{\prime} \mathrm{N}, 34^{\circ} 52.900^{\prime} \mathrm{N}$, $1067 \mathrm{~m}$, soil, 01 July 2016, 6 exs. The collecting data of $O$. hermanni specimens is: Sakarya, Kilıckaya Hill, $40^{\circ}$ 29.066' N, 30²6.464' E, $1082 \mathrm{~m}$, in soil under Quercus 
sp., 09 June 2015, 14 exs (3 exs mounted on aluminum stubs and gold-coated for scanning electron microscopy); $40^{\circ} 28.900^{\prime} \mathrm{N}, 30^{\circ} 23.510^{\prime}$ E, $598 \mathrm{~m}$, in lichen on Pinus sp., 06 November 2015, 1 ex. All materials were collected by Sedat Per.

\section{Cytogenetic procedure}

The cytogenetic method developed by Imai et al. (1988) and later modified by Gokhman and Quicke (1995) was used. The chromosome spreads were prepared from whole specimens of unknown sex. The samples were pretreated and crushed in a hypotonic solution (1\% sodium citrate) containing colchicine $(0.005 \%)$ (Sigma Aldrich, Germany). Then, the material was incubated in the hypotonic solution for $20 \mathrm{~min}$, fixed in fixative series with fixative 1 (glacial acetic acid: absolute alcohol: distilled water - 3:3:4, v:v:v), fixative 2 (glacial acetic acid: absolute alcohol - 1:1, v:v), and fixative 3 (glacial acetic acid); transferred onto pre-cleaned glass slides, air-dried and stained in 5\% Giemsa (Sigma Aldrich, Germany).

Ten metaphase plates were selected and evaluated for each species. The photos were photographed with a DP72 digital camera mounted on an Olympus BX-53 microscope and analyzed with KaryoType software loaded on a personal computer. The following parameters were evaluated: CL referring to chromosome length, THL referring to total haploid length, MHL referring to mean haploid length, and RL $=$ CL $/$ THL $\times 100$ referring to relative length. Finally, the monoploid ideograms were drawn based on chromosome lengths.

\section{RESULTS}

The chromosome records of two species are herein provided (Fig. 1), which are reported for the first time. The diploid chromosome numbers are $2 n=14$ in Oribotritia hermanni and $2 n=22$ in Hermanniella gibber and chromosomes are holocentric type (Table 1). The smallest and largest chromosome sizes are $0.38 \mu \mathrm{m}$ and $1.08 \mu \mathrm{m}$ in $O$. hermanni, respectively (Table 2 ). The total haploid chromosome length is $4.88 \mu \mathrm{m}$, in 0 . hermanni and a higher value of $6.98 \mu \mathrm{m}$ is recorded in $H$. gibber. The mean haploid length is $0.63 \mu \mathrm{m}$, in $H$. gibber, and a higher value of $0.70 \mu \mathrm{m}$ in 0 . hermanni. The relative lengths range from $5.59 \mu \mathrm{m}$ to $12.89 \mu \mathrm{m}$ in $H$. gibber and from $7.79 \mu \mathrm{m}$ to $22.13 \mu \mathrm{m}$ in 0 . hermanni. The monoploid ideograms generated by $x=7$ and 11 are given in Figure 2 .

Table 1. The comparison of chromosomal data of the species.

\begin{tabular}{lll}
\hline & $\begin{array}{l}\text { Hermanniella } \\
\text { gibber }\end{array}$ & $\begin{array}{l}\text { Oribotritia } \\
\text { hermanni }\end{array}$ \\
\hline Chromosome type & Holocentric & Holocentric \\
$x$ (basic number) & 11 & 7 \\
$\begin{array}{l}2 n \text { (diploid number) } \\
\text { Karyotype formula } \\
\text { THL (total haploid }\end{array}$ & 22 & 14 \\
$\begin{array}{l}\text { length, } \mu \mathrm{m}) \\
\text { MHL }(\mathrm{mean} \text { haploid } \\
\text { length, } \mu \mathrm{m})\end{array}$ & 6.98 & - \\
$\begin{array}{l}\text { Karyotype asymmetry } \\
\text { aryot }\end{array}$ & - & 4.88 \\
\hline
\end{tabular}

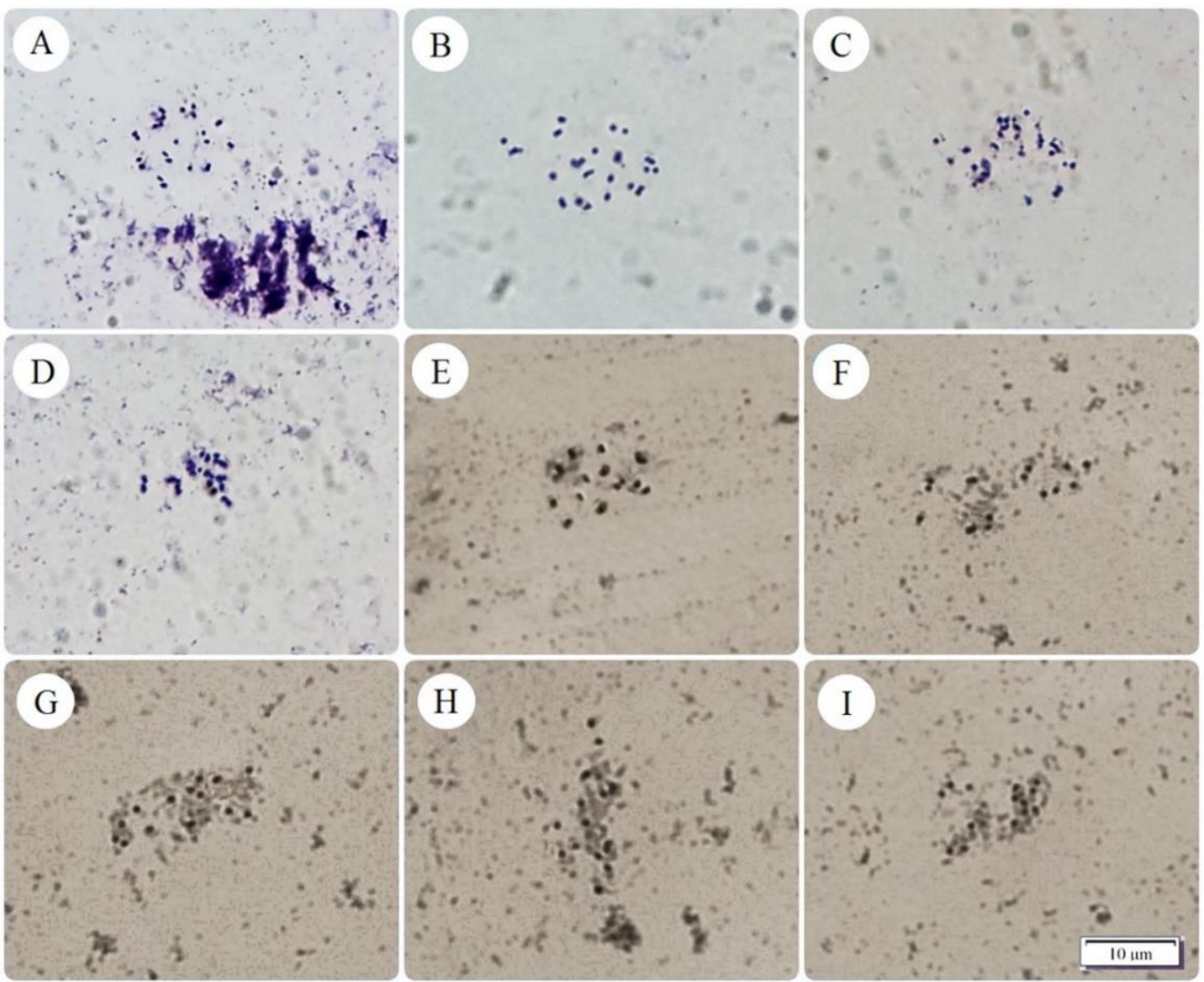

Figure 1. Photomicrograph of mitotic metaphase chromosomes, A-D. Hermanniella gibber, E-I. Oribotritia hermanni 
Table 2. The total and relative chromosome lengths of Hermanniella gibber and Oribotritia hermanni.

\begin{tabular}{|c|c|c|c|c|c|}
\hline \multicolumn{3}{|c|}{ Hermanniella gibber } & \multicolumn{3}{|c|}{ Oribotritia hermanni } \\
\hline $\begin{array}{l}\text { Chro- } \\
\text { mosome } \\
\text { Pair }\end{array}$ & $\begin{array}{l}\text { Leng } \\
\text { th } \\
(\mu \mathrm{m})\end{array}$ & $\begin{array}{l}\text { Rela- } \\
\text { tive } \\
\text { lengt } \\
\text { h (\%) }\end{array}$ & $\begin{array}{l}\text { Chromo- } \\
\text { some } \\
\text { pair }\end{array}$ & $\begin{array}{l}\text { Leng } \\
\text { th } \\
(\mu \mathrm{m})\end{array}$ & $\begin{array}{l}\text { Rela- } \\
\text { tive } \\
\text { lengt } \\
\text { h (\%) }\end{array}$ \\
\hline 1 & 0.90 & 12.89 & 1 & 1.08 & 22.13 \\
\hline 2 & 0.84 & 12.03 & 2 & 0.91 & 18.65 \\
\hline 3 & 0.81 & 11.60 & 3 & 0.73 & 14.96 \\
\hline 4 & 0.72 & 10.32 & 4 & 0.61 & 12.50 \\
\hline 5 & 0.67 & 9.60 & 5 & 0.60 & 12.30 \\
\hline 6 & 0.61 & 8.74 & 6 & 0.57 & 11.68 \\
\hline 7 & 0.57 & 8.17 & 7 & 0.38 & 7.79 \\
\hline 8 & 0.54 & 7.74 & & & \\
\hline 9 & 0.48 & 6.88 & & & \\
\hline 10 & 0.45 & 6.45 & & & \\
\hline 11 & 0.39 & 5.59 & & & \\
\hline
\end{tabular}
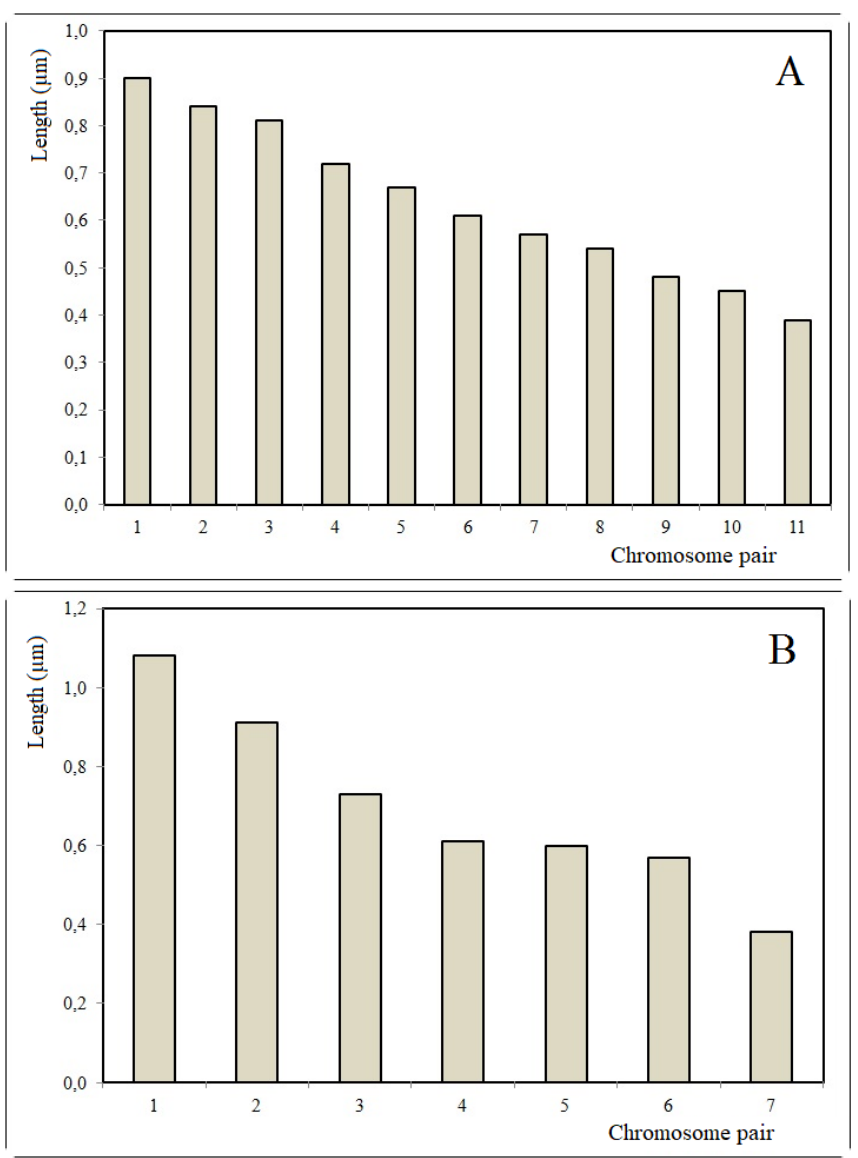

Figure 2. The monoploid ideograms of Hermanniella gibber (A) and Oribotritia hermanni (B).

\section{DISCUSSION}

The chromosomal data, which are basic chromosome number, diploid chromosome number, total haploid length, karyotype formula, centromeric index, and karyotype asymmetry etc., are important parameters for understanding the relationships among the taxa and karyotype evolution (Peruzzi and Eroğlu, 2013; Eroğlu, 2015). The diploid numbers are reported here for the first time for two oribatid mites, namely Oribotritia hermanni $(2 n=$ $14)$ and Hermanniella gibber $(2 n=22)$. The common diploid number is $2 n=18$ in oribatid mites (Norton et al.,
1993; Heethoff et al., 2006). In the present and previous relevant studies, various chromosome numbers were recorded. Eroğlu and Per (2016) reported that the chromosome number is $2 n=30$ in Zygoribatula cognata Oudemans, 1902. In addition, the diploid number is $2 n=$ 12 in Phauloppia lucorum Koch, 1841 (Gümüş et al., 2018).

The chromosomes of $H$. gibber and $O$. hermanni are small holocentric chromosomes. The holocentric chromosomes have multiple kinetochores that cover an important area along their length, rather than a single centromerespecific to monocentric chromosomes. Melters et al. (2012) assumed that the holocentric chromosomes arose at least six times overall in arthropod evolution. The holocentric chromosomes vary from 0.5 to $2.0 \mu \mathrm{m}$ (Wrensch et al., 1994). H. gibber and O. hermanni have small holocentric chromosomes (range 0.38-1.38 $\mu \mathrm{m}$ ). In Arthropoda, holocentric chromosomes are found in many orders, which are Hemiptera, Lepidoptera, Trichoptera, Dermaptera, Zoraptera, Odonata, Ephemeroptera and Oribatida (White, 1973; Heethoff et al., 2006; Melters et al., 2012). In Oribatida, Eroğlu and Per (2016) reported that Z. cognata has small holocentric chromosomes (range 0.46-1.30 $\mu \mathrm{m})$. In addition, holocentric chromosomes vary from 0.91 to $1.67 \mu \mathrm{m}$ in P. lucorum (Gümüş et al., 2018). Holocentric chromosomes have some advantages. For example, butterflies have holocentric chromosomes, so they are lower sensitivity to radiation infertility than other insect groups (North, 1967). Following radiation application, all the parts separated from the holocentric chromosome do not disappear in the anaphase phase, as they act as separate chromosomes (Lachange, 1967). In addition, adaptation to holocentric chromosomes requires different meiotic adaptations for organisms. These adaptations are asymmetric meiosis, inverted meiosis, and restriction of kinetochore activity (Melters et al., 2012).

The sex chromosomes could not be identified in H. gibber and 0 . hermanni. In addition, the oribatid mites show weak sexual dimorphism, which is the condition where the two sexes of the same species exhibit different characteristics beyond the differences in their sexual organs (Behan-Pelletier, 2015). The karyotype formulae and karyotype asymmetries could not be detected, too, because the holocentric chromosomes do not contain long and short arms.

In the present study, new chromosomal data are recorded for two species of the order Oribatida. In this respect, the results of the study provide important contributions to the cytotaxonomy of oribatid mites. Because studies on oribatid mites are very few and limited to a few reports (Norton et al., 1993; Heethoff et al., 2006; Eroğlu and Per, 2016; Gümüş et al., 2018). We think that the main reasons for the limited number of such studies are due to the organism and the method. It is difficult to work with an organism that is small and shows weak sexual dimorphism. Also, although we do have a useful method, we do not have clearer protocols like those of higher plants and animals. In addition, the increase in such studies is important in terms of understanding interspecies relations and karyotype evolution. 
Nisa Gümüș: Investigation, analysis, formal analysis, visualization, writing - original draft. Halil Erhan Eroğlu: Investigation, analysis, conceptualization, data curation methodology, visualization, software, writing - original draft. Sedat Per: Project administration, investigation, supervision, methodology, identification, writing - review and editing.

\section{Statement of ethics approval}

Not applicable.

\section{Funding}

This study was supported by the Project Coordination Application and Research Center of Yozgat Bozok University (6601-FBE/18-222).

\section{Conflict of interest}

None.

\section{Acknowledgments}

This study is part of the master's thesis of the first author. We would like to thank Biologists Kübra Çubukçu and Celalettin Şahbaz for their help during the field work.

\section{REFERENCES}

Behan-Pelletier, V. M. 2015. Review of sexual dimorphism in brachypyline oribatid mites. Acarologia, 55: 127146.

doi:10.1051/acarologia/20152163

Bezci, T. and Baran, Ş. 2016. First record of the genus Lucoppia (Acari: Oribatida) from Turkey. Turkish Journal of Zoology, 40: 765-768. doi:10.3906/zoo-1512-79

Dabert, J. 2005. Acari (mites and ticks). In: Marine parasitology. Rohde, K. (Ed.). CSIRO Publishing, Collingwood, Australia, 216-222.

Eroğlu, H.E. 2015. Which chromosomes are subtelocentric or acrocentric? A new karyotype symmetry/asymmetry index. Caryologia, 68: 239-245. doi:10.1080/00087114.2015.1032614

Eroğlu, H.E. and Per, S. 2016. Karyotype analysis of Zygoribatula cognata (Oudemans) (Acari: Oribatida: Oribatulidae). Turkish Journal of Entomology, 40: 33-38. doi:10.16970/ted.50556

Gokhman, V.E. and Quicke, D.L.J. 1995. The last twenty years of parasitic Hymenoptera karyology: an update and phylogenetic implications. Journal of Hymenoptera Research, 4: 41-63.

Gümüș, N., Per, S. and Eroğlu, H.E. 2018. Karyotype analysis of Phauloppia lucorum (Koch, 1841) (Oribatida: Oribatulidae). Turkish Journal of Entomology, 42: 7783.
Heethoff, M., Bergmann, P. and Norton, R.A. 2006. Karyology and sex determination of oribatid mites. Acarologia, 46: 127-131.

Heethoff, M., Laumann, M. and Bergmann, P. 2007. Adding to the reproductive biology of the parthenogenetic oribatid mite, Archegozetes longisetosus (Acari, Oribatida, Trhypochthoniidae). Turkish Journal of Zoology, 31: 151-159.

Imai, H., Taylor, R.W., Crosland, M.W. and Crozier, R. 1988. Modes of spontaneous chromosomal mutation and karyotype evolution in ants with reference to the minimum interaction hypothesis. The Japanese Journal of Genetics, 63 (2):159-185. doi:10.1266/jjg.63.159

Lachange, L.E. 1967. The Induction dominant lethal mutation in insects by Ionizing radiation and chemicals-as related to the steril-male technique of insect control. In: Genetic of insect vectors of diseases. Wright, J.W. and Pal, R. (Eds). Elsevier, Amsterdam, Netherlands, 617-650.

Melters, D.P., Paliulis, L.V., Korf, I.F. and Chan, S.W. 2012. Holocentric chromosomes: convergent evolution, meiotic adaptations, and genomic analysis. Chromosome Research, 20 (5): 579-593. doi:10.1007/s10577-012-9292-1

North, D.T. 1967. Radiation-induced male sterility exhibited in the P1 and F1 generations in Lepidoptera. Radiation Research, 31: 615.

Norton, R.A., Kethley, J.B., Johnston, D.E. and OConnor, B.M. 1993. Phylogenetic perspectives on genetic systems and reproductive modes of mites. In: Evolution and diversity of sex ratio in insects and mites. Wrensch, D. and Ebbert, M.A. (Eds). Chapman and Hall, New York, USA, 8-99.

Norton, R.A. and Franklin, E. 2018. Paraquanothrus n. gen. from freshwater rock pools in the USA, with new diagnoses of Aquanothrus, Aquanothrinae, and Ameronothridae (Acari, Oribatida). Acarologia, 58: 557-627. doi:10.24349/acarologia/20184258

Oliver, J.H. 1977. Cytogenetics of mites and ticks. Annual Review of Entomology, 22: 407-429. doi:10.1146/annurev.en.22.010177.002203

Peruzzi, L. and Eroğlu, H.E. 2013. Karyotype asymmetry: again, how to measure and what to measure? Comparative Cytogenetics, 7: 1-9.

doi:10.3897/CompCytogen.v7i1.4431

Schuppenhaurer, M.M., Lehmitz, R. and Xylander, W.E.R. 2019. Slow-moving soil organisms on a water highway: aquatic dispersal and survival potential of Oribatida and Collembola in running water. Movement Ecology, 7: 1-14. doi:10.1186/s40462-019-0165-5 
Subías, L.S. 2004. Systematic, synonimical and biogeographical check-list of the world's oribatid mites (Acariformes, Oribatida) (1758-2002). Graellsia, 60 (1): 3-305. (actualizado en junio de 2006, en abril de 2007, en mayo de 2008, en abril de 2009, en julio de 2010, en febrero de 2011, en abril de 2012, en mayo de 2013 y en febrero de 2014, en marzo de 2015 y en febrero de 2016, en febrero de 2017, en enero de 2018, en marzo de 2019, en enero de 2020 y en marzo de 2021). [In Spanish]

White, M.J.D. 1973. Animal cytology and evolution. Cambridge University Press, Cambridge, UK, 468 pp.
Wrensch, D.L., Kethley, J.B. and Norton, R.A. 1994. Cytogenetics of holokinetic chromosomes and inverted meiosis: Keys to the evolutionary success of mites, with generalization on eukaryotes. In: Mites: ecological and evolutionary analyses of life-history patterns. Houck, M.A. (Ed.). Chapman and Hall, New York, USA, 282343.

doi:10.1007/978-1-4615-2389-5_11

Edited by: Salih Doğan

Reviewed by: Four anonymous referees

Citation: Gümüş, N., Eroğlu, H.E. and Per, S. 2022. Karyotype analysis of two oribatid mite species (Acari: Oribatida). Acarological Studies, 4 (1): 41-45. 